\title{
Effect of probiotic on mast cell density and expression of tryptase, chymase, and TNF- $\alpha$ in the urinary bladder of rats with high cholesterol
}

\author{
Tuğrul ERTUĞRUL ${ }^{1, \mathrm{a}, \bowtie}$, Şerife TÜTÜNCÜ ${ }^{1, \mathrm{~b}}$, Gülay ÇİFTCI ${ }^{2, c}$ \\ ${ }^{1}$ Department of Histology and Embryology, Ondokuz Mayis University, Faculty of Veterinary Medicine, Samsun, Turkey; \\ ${ }^{2}$ Department of Biochemistry, Ondokuz Mayis University, Faculty of Veterinary Medicine, Samsun, Turkey. \\ ${ }^{\mathrm{a} O R C I D:}$ 0000-0002-9310-1200; bORCID: 0000-0001-6834-7244; ' ORCID: 0000-0001-5384-2381 \\ Corresponding author: tugrulertugrul06@hotmail.com \\ Received date: 22.01.2021 - Accepted date: 07.07.2021
}

\begin{abstract}
In this study, it was aimed to immunohistochemically evaluate the possible effect of probiotic supplementation on rats fed a high cholesterol diet on mast cell heterogeneity and density in the urinary bladder and on the expression of chymase, tryptase and tumor necrosis factor-alpha (TNF- $\alpha$ ) cytokine in the urinary bladder. Three groups were formed in the study. For 8 weeks, Group 1 (control group) was fed regular rat diet. Food for Group 2 (feeding $+2 \%$ cholesterol) (high cholestrol group) was provided for 8 weeks. For the last four weeks, Group 3 (\%2 cholesterol + Lactobacillus acidophilus) (probiotic group) was administered L. acidophilus probiotics. Levels of total cholesterol (TC) was measured by using a spectrophotometric autoanalyzer. Serum TC levels were remarkably increased in group 2 compared to the group $1(\mathrm{P}<0.05)$. TC decreased significantly $(\mathrm{P}<0.05)$ in group 3 compared to group 2. The number of mast cells in the control group and the probiotic group were close to each other. Only safranin O (SO) (+) mast cells was increased in the probiotic group. While there was no difference between control and high cholesterol groups, an increase in the number of tryptase mast cells was found in the probiotic group. The number of chymase mast cells declined in the probiotic group compared to control and high cholesterol groups. There was no significant difference in TNF- $\alpha$ immunoreactivity between the three groups. In conclusion, in this study, possible effects of cholesterol and probiotics on mast cell heterogeneity and expression of chymase, tryptase, TNF- $\alpha$ were revealed.
\end{abstract}

Keywords: Bladder, high cholesterol, mast cell, probiotic, TNF- $\alpha$.

\section{Probiyotiğin, yüksek kolesterolü olan sıçanların idrar kesesinde mast hücre yoğunluğu ve triptaz, kimaz ve TNF- $\alpha$ ekspresyonu üzerine etkisi}

Özet: $\mathrm{Bu}$ çalışma da yüksek kolesterollü diyet ile beslenen ratlara probiyotik ilavesinin ratların idrar kesesindeki mast hücre heterojenitesi ve yoğunluğuna olası etkisi ile mesanede kimaz, triptaz ve tümör nekroz faktör-alfa (TNF- $\alpha$ ) sitokinin ekspresyonuna etkisinin immunohistochemically değerlendirilmesi amaçladı. Grup 1 (kontrol grubu) 8 hafta boyunca standart fare yemi ile beslendi. Grup 2 (+\%2 kolesterolle beslenen) (yüksek kolestrol grubu) 8 hafta boyunca verildi. Grup 3 (\%2 kolesterol + Lactobacillus acidophilus) (probiyotik grubu): Son 4 hafta L. acidophilus probiyotiği verildi. Total kolesterol (TC) düzeyi spektrofotometrik yöntemle otoanalizör kullanılarak ölçüldü. Grup 2 serum TC düzeylerinin grup 1'e göre önemli ölçüde arttığı belirlendi $(\mathrm{P}<0,05)$. TC düzeyi Grup 3' te ise Grup 2'ye göre önemli düzeyde azaldığı belirlendi $(\mathrm{P}<0,05)$. Kontrol grubu ile probiyotik grubundaki mast hücre sayılarının birbirine yakın olduğu belirlendi. Gruplar arasında probiyotik verilen grupta sadece safranin O (SO) (+) mast hücrelerinin arttığı görüldü. Kontrol ve yüksek kolesterol grupları arasında sayısal bir fark olmamasına karşın, probiyotik verilen grupta triptaz mast hücresi sayısında bir artış bulundu. Probiyotik grubunda kimaz mast hücre sayısının kontrol ve yüksek kolesterol grubuna göre azaldığı görüldü. Üç grup arasında TNF- $\alpha$ immünoreaktivitesinde önemli bir fark yoktu. Sonuç olarak, bu çalışmada, kolesterol ve probiyotiklerin mast hücre heterojenliği ve kimaz, triptaz, TNF- $\alpha$ ekspresyonu üzerindeki olas1 etkileri gösterilmeye çalış1lmıştır.

Anahtar sözcükler: İdrar kesesi, mast hücre, probiyotik, TNF- $\alpha$, yüksek kolestrol. 


\section{Introduction}

Cholesterol is an essential lipid for maintaining cellular homeostasis. Cell membranes, hormones, and vitamin $\mathrm{D}$ are created by your body using cholesterol. It is also enriched in lipid rafts and plays a key role in intracellular signal transduction (19). Dietary cholesterol is linked to an increased risk of lung, stomach, pancreatic, rectum, colon, kidney, and bladder cancers (16). Probiotics can be regarded as an alternative choice for the prevention and treatment of chronic infection (9). They can produce antimicrobial agents and also can keep the host away from infections by attaching to specific adhesion sites on the epithelial surface of the urinary tract (15). It has been reported that chronic hyperlipidemia leads to detrusor overactivity and detrusor inadequate activity, which cause developmental mechanisms of urinary bladder dysfunction (39).

Mast cells located in areas associated with the external environment detect potentially harmful substances (31). Mast cells are commonly found in systems such as the skin, respiratory and digestive systems. They're among the first cell groups in the defense mechanism against pathogens and foreign object entry because of this distribution. These cells can also be found in the connective tissue of the genital and urinary systems and around blood vessels and peripheral nerves (12). Mast cells can also function as antigen-presenting cells by processing bacteria and antigens. The most distinctive morphological feature of mast cells is secretory granules found in their cytoplasms such as biogenic amines, proteoglycans, and cytokines. When mast cells are stained with granule-specific dyes such as alcian blue and safranin $\mathrm{O}$, they are divided into three subgroups according to their histochemical differences: alcian blue $(\mathrm{AB})(+)$, safranin $\mathrm{O}(\mathrm{SO})(+)$, and $\mathrm{AB} / \mathrm{SO}(+)$ (mixed) (13). Mast cells have a large number of co-stimulatory molecules. Among these mediators is the tumor necrosis factor-alpha (TNF- $\alpha$ ), which allows them to interact with different cell populations (34).

Mast cells are immunohistochemically classified into two subgroups based on the distribution of neutral proteases, tryptase positive $\left(\mathrm{MC}_{\mathrm{T}}\right)$ and chymase-positive mast cells $\left(\mathrm{MC}_{\mathrm{TC}}\right)$. Tryptase, which is used as a marker for mast cell activation, is the most abundant secretory granule-derived serine proteinase contained in mast cells. Tryptase is known to participate in angiogenesis, the degradation of the fibrous and amorphous component of the extracellular matrix of connective tissue, and indirectly the release of growth factors, including matrix metalloproteinases (3). Chymases, which are neutral serine proteases, are significant components of mast cell granules. Chymase plays a role in remodeling the extracellular matrix of the connective tissue, inflammation, allergy, and angiogenesis mechanisms.
Also, it inhibits the production of some pro-inflammatory cytokines while promoting neutrophil and eosinophil migration (32). TNF- $\alpha$ is an inflammatory cytokine responsible for a diverse range of signaling events within cells. TNF- $\alpha$ has various therapeutic functions in the body, including immunostimulation, infection resistance, tumor resistance, sleep regulation, and embryonic development. Also, TNF- $\alpha$ has the ability to cause necrotic or apoptotic cell death (18).

The purpose of this study was to investigate the possible effects of high cholesterol and probiotics on mast cell heterogeneity and density in the rat urinary bladder. Besides, chymase, tryptase neutral proteases and TNF- $\alpha$ cytokine expression in the urinary bladder were evaluated immunohistochemically.

\section{Materials and Methods}

The experimental protocol and all animal procedures were approved by the Experimental Ethics Committee. In the study, a power analysis was conducted by using the G*Power (3.1.9.3) software, and according to the result of the power analysis (95\% power, $\alpha=0.05$ ), 3 groups rats $(n=7)$. In our study, we used a total of 21 Sprague Dawley adult male rats, 7 in each group. Rats were engaged under standard experimental laboratory conditions (temperature: $24^{\circ} \mathrm{C}$; dark/light cycle: $12 / 12$ hours; free arrival to food and water; relative humidity: 60\%). Experimental animals were fed ad libitum throughout the study. The rats were randomly assigned to three groups.

In order to form high cholesterol, $2 \%$ cholesterol was added to standard rat feed and it was pelleted again after mixing homogeneously. The probiotic Lactobacillus acidophilus to be used for treatment in the study was purchased as lyophilized. After diluting the lyophilized bacteria with De Man, Rogosa ve Sharpe Agar (MRS Agar) broth, it was inoculated on 5\% sheep blood agar for viability and purity control. It was added in an amount of $1 \mathrm{ml}$ to the tube containing $9 \mathrm{ml}$ MRS from the culture determined to be alive and pure and left to incubate at $37^{\circ} \mathrm{C}$ for 18 hours. At the end of the period, suspensions were prepared with physiological saline up to $10^{9}$ from liquid culture. Three of these suspensions were seeded on blood agar and left incubation for 18 hours at $37^{\circ} \mathrm{C}$. After the incubation, bacterial colonies grown on the plates were counted and the number of bacteria in the main culture was calculated. After the calculation, the suspension was made to contain $10^{9} \mathrm{kob} / \mathrm{ml}$ bacteria in the main culture and Lactobacillus acidophilus probiotic suspension to be used for treatment was prepared.

Group 1 (control group): The male adult 7 rats were fed with standard pellet rat feed for 8 weeks. Group 2 (feeding $+2 \%$ cholesterol) (high cholestrol group): The male adult 7 rats were fed with a ration of $2 \%$ cholesterol added to the standard feed for 8 weeks and high 
cholesterol was formed (28). Group 3 (2\% cholesterol + Lactobacillus acidophilus) (probiotic group): The male adult 7 rats were fed for 8 weeks with a ration containing $2 \%$ cholesterol in the standard feed, and in the last 4 weeks of the trial, Lactobacillus acidophilus probiotics containing $2 \times 10^{8} \mathrm{kob} / \mathrm{ml} /$ day were administered via oral gavage (37).

At the end of the eight-week experimental period, the rats were fasted for 12 hours before weighed one by one, allowing only normal drinking water. Rats were anesthetized with $10 \%$ ketasol $(0.8-1.3 \mathrm{ml} / \mathrm{kg})$ and $2 \%$ basilazine $(2-5 \mathrm{mg} / \mathrm{kg})$ via IP and blood samples were taken from the heart. Blood samples were leaved to stand for 20 minutes in the laboratory for allowed clotting, and then centrifuged for $10 \mathrm{~min}$ at $1550 \mathrm{xg}$. The sera were extracted and divided into aliquots. Sera were stored at $80{ }^{\circ} \mathrm{C}$ until used for the analyses.

The rats in all groups were sacrificed after 8 weeks later their urinary bladder tissues were taken. The urinary bladders of the rats were fixed in $10 \%$ formaldehyde solution (Sigma-Aldrich, S2BF1830V) for histological examination. Following this, they were blocked in paraffin after undergoing routine tissue processing procedures.

Serum total cholesterol: Total cholesterol level was measured by serum biochemistry autoanalysers (Autolab, AMS srl, Aotuanalyzer, Netherlands) using commercial autoanalyzer test kits (Audit Diagnostics, Ireland).

Mast cell histochemistry: In the urinary bladder blocks, 10 serial sections of $5 \mu \mathrm{m}$ thickness were taken at $30 \mu \mathrm{m}$ intervals. Cross-sections were stained with toluidine blue (Sigma-Aldrich, 92-31-9) (0.5\% and $\mathrm{pH}=0.5$ ) for 10 minutes. In order to determine subtypes of mast cells, $5 \mu \mathrm{m}$ thick sections with $30 \mu \mathrm{m}$ intervals were taken from each block and stained with alcian blue (Sigma-Aldrich, 22864-99-2)/safranin O (Sigma-Aldrich, 477-73-6) (AB/SO) combined staining method (11).

In the serial sections prepared to find out the numerical distribution of mast cells, cell counts were performed with 100 squares ocular micrometer. The mast cells at 100 square units of the ocular micrometer were counted with a magnification of X40. Cell count was performed at 10 randomly chosen different areas of the sections receipt from bladder and the arithmetic mean of the results was taken. All the data obtained by calculating the square of 100 square ocular micrometer for X40 objective magnification with the help of micrometric lame were turned into mast cell number within a unit area of 1 $\mathrm{mm}^{2}$.

Immunohistochemistry: The urinary bladder sections $5 \mu \mathrm{m}$ thick taken from paraffin blocks were stained immunohistochemically by using anti-rabbit polyclonal chymase (1/200 dilution, Biorbyt, orb11030), mouse monoclonal tryptase (1/200 dilution, Abcam, ab2378) and rabbit polyclonal TNF- $\alpha$ (1/200 dilution,
Abcam, AB-9739) primary antibodies with Streptavidin biotin complex method (35). Histostain Plus (Zymed kit: 85-6743) kit was performed as secondary antibody. After deparaffinization, sections were heated in a microwave oven of 700 watts within citrate buffer $(\mathrm{pH}=6)$ solution for proteolysis. In order to block endogenous peroxidase activity, the tissues were incubated in 3\% hydrogen peroxide solution. Following washing with phosphate buffer solution (PBS), serum in the kit was instilled to prevent nonspecific protein binding in sections. Primary antibody was applied on sections and they were stored at $+4{ }^{0} \mathrm{C}$ for overnight. Only PBS solution was process on negative control group tissues. Following the washing procedure, biotinylated secondary antibody was instilled into sections and incubated at streptavidin-horseradish peroxidise complex after washing. As the last stage, 3, 3'diaminobenzidine (DAB) (Abcam, ab64264) was used as chromogen and the preparations were covered with entellan by counterstaining was performed with hematoxylin.

Statistical analysis: The number of mast cell were analyzed with one-way ANOVA and determination of the significance of differences between the groups was done with Duncan's test. Differences among the groups $\mathrm{P}<0.05$ was accepted to be significant. SPSS statistical software was used for analyses (IBM - Company, Armonk, NYUSA, version 21).

$\mathrm{AB}(+), \mathrm{SO}(+), \mathrm{AB} / \mathrm{SO}(+)$ (mixed), $\mathrm{MC}_{\mathrm{T}}$ and $\mathrm{MC}_{\mathrm{TC}}$ distribution was evaluated semiquantitatively. In semiquantitative evaluation following criteria were used; no positive cell in the scanned area (-), 1-2 cells $( \pm), 3-4$ cells $(+)$, and 5-6 cells $(++)$. Quantitative evaluation was made according to the positive staining intensity. Staining intensity of TNF- $\alpha$ expression was scored as; 0 , no immunoreactive detected; +/-, weakly positive staining present; +, moderate positive staining present; ++, strongly positive staining present.

\section{Results}

Serum total cholesterol levels: Total cholesterol (TC) level of Group 1, Group 2 and Group 3 were $51.14 \pm 1.56,76.71 \pm 1.97,62 \pm 1.3(\mathrm{mg} / \mathrm{dl})$, respectively. It was determined that TC level increased significantly in Group $2(\mathrm{P}<0.05)$ and begun to decrease in Group 3.

\section{Histochemical findings}

Toluidine blue staining: Mast cells showed metachromasia and their granules could not selected individually. They were in different sizes with round, oval or spindle shaped. Nuclei of the cells were covered by granules in most of the cells (Figure 1A). Mast cells observed in urothelium, submucosa, lamina propria (Figure 1B), and detrusor muscle layer. It was noteworthy that they were localized around capillaries in the lamina propria (Figure 1C), and close to detrusor smooth muscle 
cells. When the groups were evaluated, the number of mast cells were lower in the control group. The number of mast cells in the control group and the probiotic group were close to each other. The change in the number of mast cells in the urinary bladder was not statistically significant $(\mathrm{P}>0.05)$ (Table 1).

AB/SO combine staining: The application of the alcian blue/safranin $\mathrm{O}$ staining technique demonstrated that three types of cells, including in blue $\mathrm{AB}(+)$ cells, in pink-red SO $(+)$ cells, and red-blue $\mathrm{AB} / \mathrm{SO}(+)$ (mixed) cells, were present in the urinary bladder (Figures $2 \mathrm{~A}$ and 2B). It was seen that mast cells stained $\mathrm{SO}(+)$ in the urinary bladder were numerically higher than $\mathrm{AB}(+)$ and
$\mathrm{AB} / \mathrm{SO}(+)$ stained mast cells. Among the groups, only the $\mathrm{SO}(+)$ mast cells increased in the probiotic given group (Figure 2C) (Table 2).

Table 1. Mast cell counts after staining with toluidine blue in three groups $(\mathrm{P}>0.05)$.

\begin{tabular}{llc}
\hline Groups & $\mathbf{n}$ & $\mathbf{X} \pm \mathbf{S x}$ \\
\hline Group 1 & 7 & $12.38 \pm 0.09$ \\
Group 2 & 7 & $14.03 \pm 0.18$ \\
Group 3 & 7 & $13.11 \pm 0.65$ \\
\hline
\end{tabular}

Table 2. Mast cell counts after staining with alcian blue/safranin O combined staining and tryptase and chymase positive cell reaction in bladder. No positive cell (-), 1-2 cells $( \pm), 3-4$ cells $(+)$, and 5-6 cells (++).

\begin{tabular}{|c|c|c|c|}
\hline Mast Cells & Control group & High cholesterol group & Probiotic group \\
\hline $\mathrm{AB}(+)$ & \pm & \pm & \pm \\
\hline $\mathrm{SO}(+)$ & + & + & ++ \\
\hline $\mathrm{AB} / \mathrm{SO}(+)$ & \pm & \pm & \pm \\
\hline Tryptase-mast cell & + & + & ++ \\
\hline Chymase-mast cell & ++ & ++ & + \\
\hline
\end{tabular}

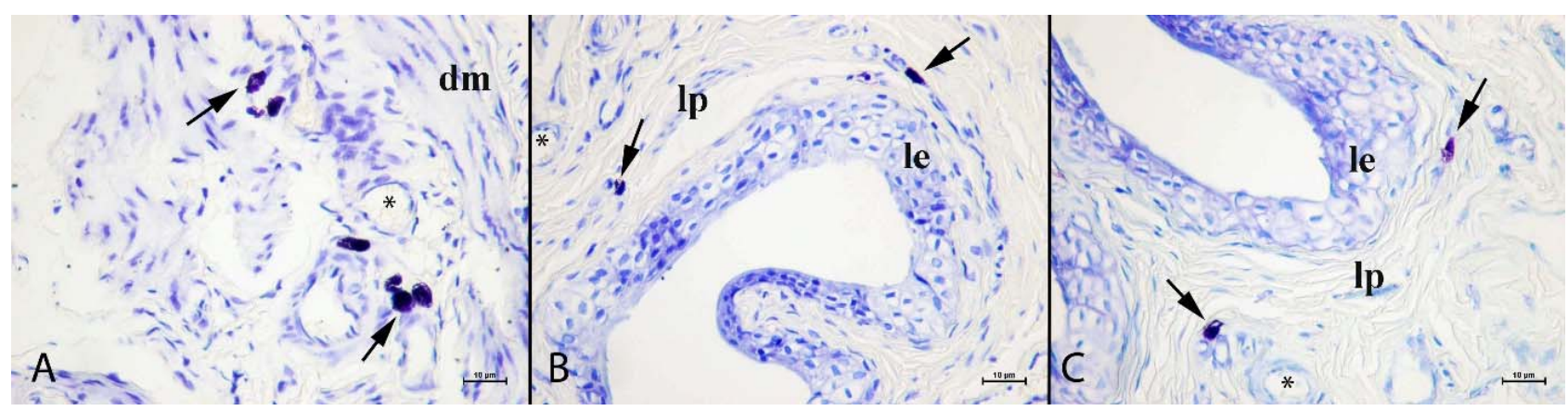

Figure 1. A Group 1, B group 2, C group 3, toluidine blue staining; le (lamina epithelialis), lp (lamina propria), dm (detrusor muscle), arrow: metachromatic mast cells, blood vessel (asterix), original magnification X40; range bar, $10 \mu \mathrm{m}$.

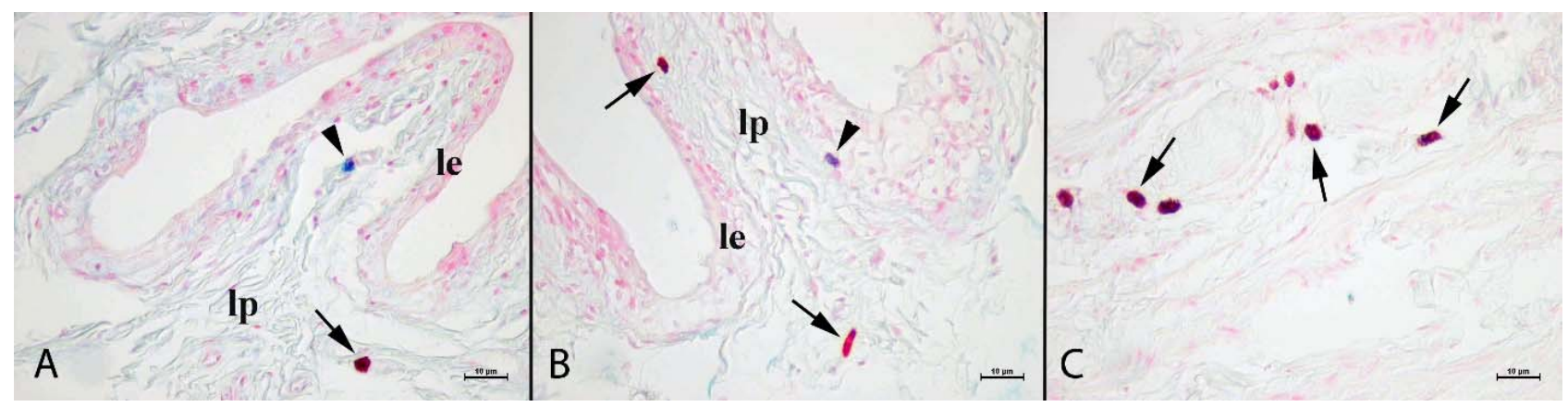

Figure 2. Alcian blue/safranin O combined staining method; A group 1, arrow: $\mathrm{SO}(+)$ mast cell, arrowhead: AB (+) mast cell, B group 2, arrow: SO $(+)$ mast cell, arrowhead: mixed type mast cell, le (lamina epithelialis), lp (lamina propria), C group 3, arrow: SO $(+$ ) mast cell, original magnification X40; range bar, $10 \mu \mathrm{m}$. 


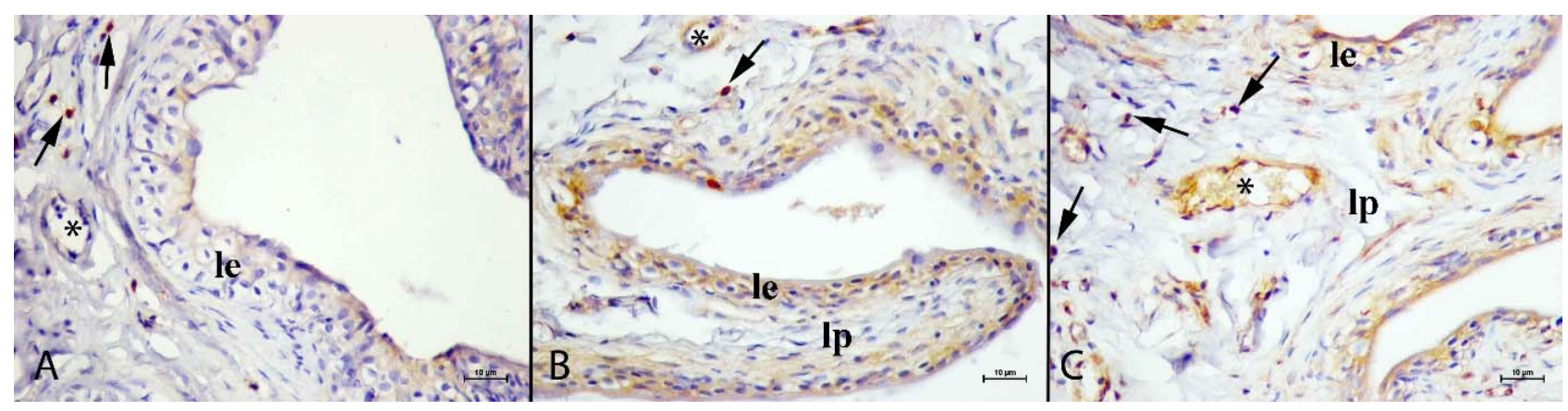

Figure 3. Tryptase immunostaining A group 1, B group 2, C group 3, le (lamina epithelialis), lp (lamina propria), dm (detrusor muscle), arrow: tryptase-positive mast cells, blood vessel (asterix), original magnification X40; range bar, $10 \mu \mathrm{m}$.

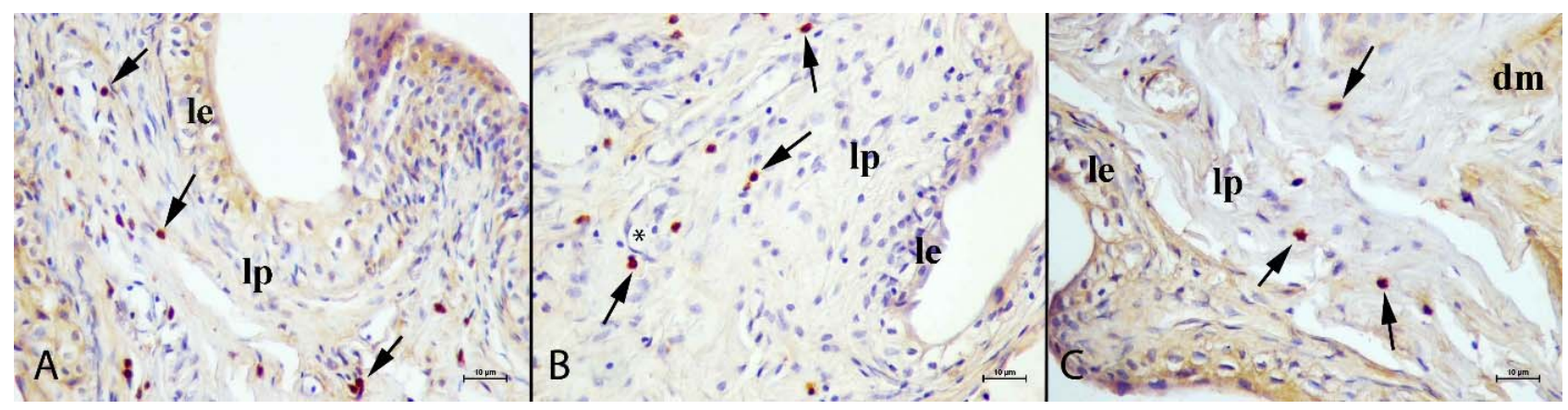

Figure 4. Chymase immunostaining A group 1, B group 2, C group 3, le (lamina epithelialis), lp (lamina propria), dm (detrusor muscle), arrow: chymase-positive mast cells, blood vessel (asterix), original magnification X40; range bar, $10 \mu \mathrm{m}$.
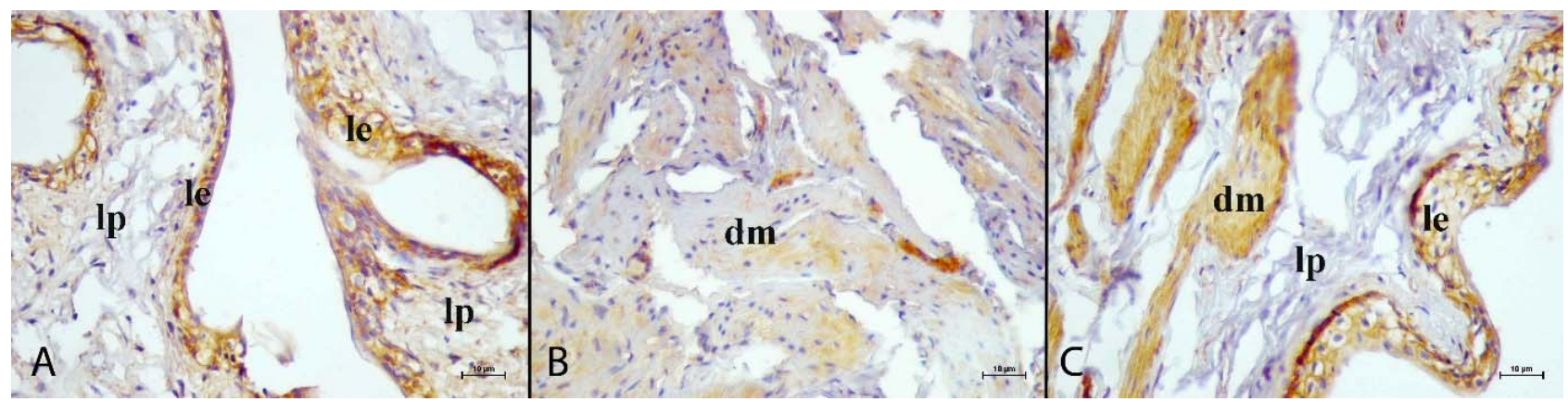

Figure 5. Tumor necrosis factor alpha immunostaining A group 1, B group 2, C group 3, TNF- $\alpha$ immunoreactivity, le (lamina epithelialis), lp (lamina propria), dm (detrusor muscle), original magnification X40; range bar, $10 \mu \mathrm{m}$.

\section{Immunohistochemical findings}

Tryptase-positive mast cell expression: In all groups, oval and round-shaped $\mathrm{MC}_{\mathrm{T}} \mathrm{S}$ were observed in the urinary bladder (Figure $3 \mathrm{~A}$ ). $\mathrm{MC}_{\mathrm{T}} \mathrm{S}$ were present in the urothelium and submucosa (Figure 3B), including the lamina propria, as well as for the detrusor smooth muscle layer. $\mathrm{MC}_{\mathrm{T}} \mathrm{s}$ were seen especially around the blood vessels in the submucosa (Figure 3C). While there was no numerical difference between the control and high cholesterol groups, an increase in the number of $\mathrm{MC}_{\mathrm{TS}}$ was found in the probiotic given group (Table 2).

Chymase-positive mast cell expression: In the urinary bladder oval, round, or spindle-shaped $\mathrm{MC}_{\mathrm{TC}} \mathrm{S}$ were detected in all layers, especially around the blood vessels (Figures $4 \mathrm{~A}$ and $4 \mathrm{~B}$ ). $\mathrm{MC}_{\mathrm{TC}}$ s were localized in the mucosa especially in the lamina propria (Figure 4C). In the detrusor layer, they were predominantly detected close to smooth muscle cells (Figure 4). The number of $\mathrm{MC}_{\mathrm{TCS}}$ decreased in the probiotic group compared to the control and high cholesterol group (Table 2).

TNF- $\alpha$ expression: TNF- $\alpha$ immunoreactivity was observed throughout the transitional epithelium as a brown color in the urinary bladder. Membrane like and intracytoplasmically immunopositive staining were determined epithelial cells (Figures 5A and 5B). Analysis of the tissue preparations of each of the groups revealed the immunoreactivity of TNF- $\alpha$ antibodies in detrusor muscle cells intracytoplasmic staining (Figure 5C). There was no significant difference in TNF- $\alpha$ immunoreactivity between the three groups (Table 3 ). 
Table 3. Immunoreactivity of TNF- $\alpha$ in bladder; +/-, weakly positive staining present; + , moderate positive staining present; ++ , strongly positive staining present.

\begin{tabular}{lccc}
\hline & Control group & High cholesterol group & Probiotic group \\
\hline TNF- $\alpha$ & ++ & ++ & ++ \\
\hline
\end{tabular}

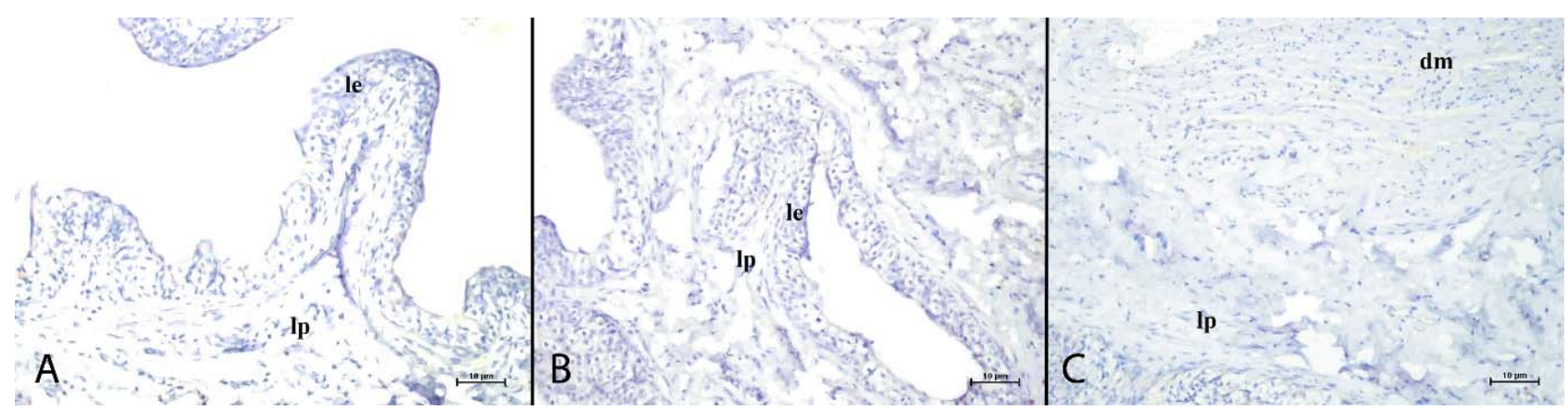

Figure 6. Immunohistochemistry staining negative control A tryptase immunostaining, B chymase immunostaining, C TNF- $\alpha$ immunostaining, le (lamina epithelialis), lp (lamina propria), dm (detrusor muscle), original magnification X20; range bar, $10 \mu \mathrm{m}$.

Also, tryptase, chymase, and TNF- $\alpha$ immunoreactions were not observed in the negative control groups when immunostaining was performed on urinary bladder tissue for control purposes (Figure 6).

\section{Discussion and Conclusion}

Studies have shown that certain probiotic strains can reduce inflammation and significantly impact immune cells and inflammation (34). Bacteria and mast cells are thought to interact with each other via useful stabilizing agents. The Histamine H1 receptor blocker diphenhydramine, for example, was shown in one study to inhibit the increase of cytokines from mast cells stimulated by bacteria (27). Probiotic VSL \# 3 is known to have a reducing effect on mast cells that increase in visceral hypersensitivity (23). Cholesterol can cause very high levels of mast cell activation in mice fed a high cholesterol diet (40). Previous studies have shown that the probiotic bacteria Bifidobacterium bifidum BGN4 and Lactobacillus casei 911 reduce ovalbumin-induced mast cell degranulation in ear and tongue tissue samples of mice (21). Several studies in rodent models have shown that $L$. rhamnosus GG and some other probiotic strains have a decreasing effect on mast cell numbers (4). Furthermore, following oral treatment of E. faecalis, which reduced mast cell infiltration in a murine model, the role of commensal microorganisms in controlling mast cell activation was demonstrated (7). In addition, some broadspectrum antibacterial agents are known to inhibit mast cell activation and degranulation. Also, it was demonstrated that different strains of Lactobacilli can suppress mast cell degranulation (34). In the study investigating the effect of probiotics on aspirin-induced gastric mucosal lesions, it was observed that the number of mast cells was not significantly different between the control and probiotic plus aspirin groups (33). In the light of the findings of our studies and previous studies, we suggest that probiotics have the ability to affect mast cell numbers as well as beneficial effects in the organism.

Two subtypes of mast cells were defined based on their physiological, staining characteristics, functional variety, and morphology. These cells are stained differently in terms of the proteoglycan type and protease content (11). In a study investigating the phenotypic heterogeneity of mast cells in rat kidney, three kinds of mast cells have been determined with $\mathrm{AB} / \mathrm{SO}$ staining method. In studies examining mast cell subtypes in rat kidney (12) and rat small intestine (8), SO (+) mast cells were the most common subtype. It has been reported that more SO $(+)$ mast cells were detected in the ovarian tissue of rats treated with experimental capsaicin (36). In our study, we found three subtypes of mast cells with $\mathrm{SO}(+)$, $\mathrm{AB}(+)$, and $\mathrm{AB} / \mathrm{SO}(+)$ staining in all groups. We observed that feeding a high-cholesterol diet had no direct effect on mast cell heterogeneity in our research. On the other hand, the probiotic group had the highest number of SO (+) stained mast cells. Based on our findings, we hypothesized that probiotics may influence mast cell heterogeneity in the rat urinary bladder.

Previous work has reported that $\mathrm{MC}_{\mathrm{T}} \mathrm{S}$ were observed in urothelium and submucosa, including the lamina propria, as well as for the detrusor muscle layer in the bladder (29). It was found that $\mathrm{MC}_{\mathrm{T}} \mathrm{S}$, which increased in urinary bladder damage caused by protamine sulfate, decreased when montelukast was given (6). Ketamine caused a significant increase in the numbers of $\mathrm{MC}_{\mathrm{T}} \mathrm{S}$ in the urinary bladder (22). In studies investigating the tryptase expression, it was found that in the bladder, montelukast against stress (10) and non-Hunner type interstitial cystitis (1) did not cause a significant increase 
in the number of mast cells. We postulated that the high cholesterol diet did not directly affect the number of $\mathrm{MC}_{\mathrm{T}} \mathrm{S}$ in the rat urinary bladder, whereas probiotics might have an effect on the number of $\mathrm{MC}_{\mathrm{T}} \mathrm{S}$.

In the study of hyperlipidemia on the heart tissue, the expression of chymase increased in the experimental group compared to the control group (5). Studies have shown that $\mathrm{MC}_{\mathrm{TC}} \mathrm{S}$ increase in the urinary bladder lamina propria (25), mucosa, and detrusor layer as a result of interstitial cystitis (38). Nedocromil treatment can reduce the number of chymase positive cells in diabetic mice (17). In previous studies, it was found that hormonal mechanism changes (14) and capsaicin administration (36) did not cause a change in $\mathrm{MC}_{\mathrm{TC}}$ count. It was observed that the number of $\mathrm{MC}_{\mathrm{TC}} \mathrm{S}$ in the urinary bladder of rats fed with probiotics decreased. Furthermore, it was found that high cholesterol did not lead any change in chymase expression. Based on the findings we obtained in this study, we speculated that probiotics may play an important role in the attitude of $\mathrm{MC}_{\mathrm{TC}}$ in the rat urinary bladder.

In a study examining the immunomodulatory and anti-inflammatory capacities of probiotics, it has been reported that there was no difference in TNF- $\alpha$ densities between the control and experimental groups (26). It has also been shown that TNF- $\alpha$ expression was elevated in bladder inflammation (30). It has been observed that the expression intensity of TNF- $\alpha$, one of the main active substances produced by mast cells, was significantly reduced in mast cell-deficient mice (24). The previous study reported an increase in mast cell count, strong mast cell tryptase, and TNF- $\alpha$ staining in allergic conjunctivitis (20). Besides, Pycnogenol has been reported to reduce both the number of mast cells and TNF- $\alpha$ staining (2). In our study, we could not find differences in TNF- $\alpha$ expression in the bladder among three groups. Although there was a difference in mast cell numbers between the groups in our study, it was statistically insignificant. Also, there was no difference between the control and high cholesterol groups in semi-quantitative evaluations of tryptase and chymase mast cells. The results obtained from this study show that the probiotic cannot directly affect the TNF- $\alpha$ expression in the urinary bladder.

In conclusion, to the best of our knowledge, this study is the first to show that cholesterol and probiotics may induce mast cell heterogeneity and chymase, tryptase, and TNF- $\alpha$ expression in the rat urinary bladder. The results of this study display that cholesterol and probiotic administration may cause changes, although not significantly, in mast cell heterogeneity and numbers in the urinary bladder. Other important findings of this study were that high cholesterol and probiotics may not affect TNF- $\alpha$ expression in the bladder. Taken together, these findings show how cytokines and mast cells respond to active substances in metabolism. However, this study is based on an animal model, and more clinical studies are needed to evaluate the effects of high cholesterol and probiotics on the urinary bladder.

\section{Financial Support}

This research received no grant from any funding agency/sector.

\section{Ethical Statement}

In the presented study, increasing samples of the project numbered PYO.VET.1904.16.019, which was approved by the Ondokuz Mayis University Animal Experiments Local Ethics Committee (2016/27) and supported by the Scientific Research Projects of Ondokuz Mayıs University, were used.

\section{Conflict of Interest}

The authors declared that there are no conflicts of interest. The authors are responsible for the content and writing of the paper.

\section{References}

1. Akiyama Y, Maeda D, Morikawa T, et al (2018): Digital quantitative analysis of mast cell infiltration in interstitial cystitis. Neurourol Urodyn, 37, 650-657.

2. Akyuz AI, Kocaturk UT, Gunel C, et al (2018): Effect of Pycnogenol $^{\mathbb{B}}$ on an experimental rat model of allergic conjunctivitis. Graefes Arch Clin Exp Ophthalmol, 256, 1299-1304.

3. Atiakshin D, Buchwalow I, Samoilova V, et al (2018): Tryptase as a polyfunctional component of mast cells. Histochem Cell Biol, 149, 461-477.

4. Cassard L, Lalanne AI, Garault P, et al (2016): Individual strains of Lactobacillus paracasei differentially inhibit human basophil and mouse mast cell activation. Immun Inflam Dis, 4, 289-299.

5. Cheng Y, Zhu Y, Zhang J, et al (2017): Large accumulation of collagen and increased activation of mast cells in hearts of mice with hyperlipidemia. Arq Bras Cardiol, 109, 404-409.

6. Çetinel Ş, Çanılıoğlu YE, Çikler E, et al (2011): Leukotriene D4 receptor antagonist montelukast alleviates protamine sulphate-induced changes in rat urinary bladder. BJU Int, 107, 1320-1325.

7. De Zuani M, Dal Secco C, Frossi B (2018): Mast cells at the crossroads of microbiota and IBD. Eur J Immunol, 48, 1929-1937.

8. Demirbă̆ E, Çınar K, Kutlar MH, et al (2012): Distribution and heterogenity of mast cells in small intestine of rat (Rattus rattus). SDÜ Fen Dergisi, 7, 92-99.

9. Doron S, Gorbach SL (2006): Probiotics: Their role in the treatment and prevention of disease. Exp Rev Anti Infect Ther, 4, 261-275.

10. Dülger EÇ, Çanıllığlu YE, Çetinel Ş, et al (2018): Protective Effects of Montelukast Against Stress-Induced Degeneration of the Urinary Bladder. Clin Exp Health Sci, 8, 211-216. 
11. Enerback L (1966): Mast cells in rat gastrointestinal mucosa: 1. Effects of fixation. Acta Pathol Microbiol Scand, 66, 289-302.

12. Ertuğrul T, Çiftci G, Tütüncü Ş (2017): Heterogeneity and distribution of mast cells in renal tissues of rats exposed to formaldehyde. Vet Hekim Der Derg, 88, 26-37.

13. Ertugrul T, Tutuncu S, Kabak M, et al (2018): The distribution and heterogeneity of mast cells in tongue from five different avian species. Anat Histol Embryol, 47, 306312.

14. Hayıroğlu AE, Karaca T, Demirtaş S (2016): Streptozotocin-Induced diabetic that histochemical and immunohistochemical examination of mast cells distribution in ovary and uterus during different stages of estrous cycle in rats. Kafkas J Med Sci, 6, 29-37.

15. Homayouni A, Bastani P, Ziyadi S, et al (2014): Effects of probiotics on the recurrence of bacterial vaginosis: a review. J Low Genit Tract Dis, 18, 79-86.

16. Hu J, La Vecchia C, de Groh M, et al (2012): Dietary cholesterol intake and cancer. Ann Oncol, 23, 491-500.

17. Huang ZG, Jin Q, Fan M, et al (2013): Myocardial remodeling in diabetic cardiomyopathy associated with cardiac mast cell activation. PLoS One, 8, e60827.

18. Idriss HT, Naismith JH (2000): TNF and the TNF receptor superfamily: structure-function relationship(s). Microsc Res Tech, 50, 184-195.

19. Ikonen E (2008): Cellular cholesterol trafficking and compartmentalization. Nat Rev Mol Cell Biol, 9, 125-38.

20. Kocatürk T, Ünsal AİA, Günel C, et al (2020): The effect of thymoquinone on experimental model of allergic conjunctivis. KOU Sag Bil Derg, 6, 17-22.

21. Kim H, Kwack K, Kim YD, et al (2005): Oral probiotic bacterial administration suppressed allergic responses in an ovalbumin-induced allergy mouse model. FEMS Immunol Med Microbiol, 45, 259-267.

22. Li M, Yang K, Wang X, et al (2015): Mast cells infiltration and decreased E-cadherin expression in ketamine-induced cystitis. Toxicol Rep, 2, 205-209.

23. Li YJ, Li J, Dai C (2020): The Role of Intestinal Microbiota and mast cell in a rat model of visceral hypersensitivity. $\mathrm{J}$ Neurogastroenterol Motil, 6, 529-538.

24. Liu C, Ouyang W, Xia J, et al (2018): Tumor Necrosis Factor- $\alpha$ Is Required for Mast Cell-Mediated Host Immunity Against Cutaneous Staphylococcus aureus Infection. J Infect Dis, 218, 64-74.

25. Malik ST, Birch BR, Voegeli D, et al (2018). Distribution of mast cell subtypes in interstitial cystitis: implications for novel diagnostic and therapeutic strategies? J Clin Pathol, 71, 840-844.

26. Oksaharju A, Kooistra T, Kleemann R, et al (2013): Effects of probiotic Lactobacillus rhamnosus $G G$ and
Propionibacterium freudenreichii ssp. Shermanii JS supplementation on intestinal and systemic markers of inflammation in ApoE*3Leiden mice consuming a high-fat diet. Br J Nutr, 119, 77-85.

27. Oksaharju A, Kankainen M, Kekkonen, et al (2011): Probiotic Lactobacillus rhamnosus downregulates FCER1 and HRH4 expression in human mast cells. World J Gastroenterol, 17, 750-759.

28. Onody A, Csonka C, Giricz Z, et al (2003): Hyperlipidemia Hinduced by a cholesterol-rich diet leads to enhanced peroxynitrite formation in rat hearts. Cardiovasc Res, 58, 663-670.

29. Oottamasathien S, Jia W, Roundy LM, et al (2013): Physiological relevance of LL-37 induced bladder inflammation and mast cells. J Urol, 190, 1596-1602.

30. Ozguven AA, Yılmaz O, Taneli F, et al (2014): Protective effect of ketamine against hemorrhagic cystitis in rats receiving ifosfamide. Indian J Pharmacol, 46, 147-151.

31. Palm NW, Rosenstein RK, Medzhitov R (2012): Allergic host defences. Nature, 484, 465-472.

32. Pejler G (2020): Novel insight into the in vivo function of mast cell chymase: lessons from knockouts and inhibitors. J Innate Immun, 12, 357-372.

33. Şenol A, Işler M, Karahan AG, et al (2011): Effect of probiotics on aspirin-induced gastric mucosal lesions. Turk J Gastroenterol, 22, 18-26.

34. Traina G (2019): Mast Cells in Gut and Brain and Their Potential Role as an Emerging Therapeutic Target for Neural Diseases. Front Cell Neurosci, 13, 345.

35. True LD (1990): Principles of immunohistochemistry. Gower Medical Publishing, New York.

36. Tutuncu Ş, Ertugrul T (2019): Immunohistochemical expression of tryptase- chymase and mast cell heterogeneity in capsaicin-treated rat ovaries. IJVAR, 2, 25-31.

37. Wang L, Zhou B, Zhou X, et al (2019): Combined lowering effects of rosuvastatin and $l$. acidophilus on cholesterol levels in rat. J Microbiol Biotechnol, 29, 473481.

38. Yamada T, Murayama T, Mita H, et al (2000): Subtypes of bladder mast cells in interstitial cystitis. Int J Urol, 7, 292-297.

39. Yoshida M, Kudoh J, Masunaga K, et al (2010): The effects of chronic hyperlipidemia on bladder function in myocardial infarction-prone Watanabe heritable hyperlipidemic (WHHLMI) rabbits. Neurourol Urodyn, 29, 1350-1354.

40. Zhanga X, Huang Q, Wang X, et al (2019): Dietary cholesterol is essential to mast cell activation and associated obesity and diabetes in mice. Biochim Biophys Acta Mol Basis Dis, 1865, 1690-1700. 